\title{
Uranium-bearing francolites present in organic-rich limestones of NW Greece: a preliminary study using synchrotron radiation and fission track techniques
}

\author{
I. T. Tzifas ${ }^{1}$ - U. A. Glasmacher ${ }^{2}$ P. Misaelides ${ }^{1} \cdot$ A. Godelitsas $^{3}$. \\ P. N. Gamaletsos ${ }^{4,5} \cdot$ J. Goettlicher ${ }^{4}$ D. Françoso de Godoy ${ }^{6}$
}

Received: 9 June 2016/Published online: 4 August 2016

(C) Akadémiai Kiadó, Budapest, Hungary 2016

\begin{abstract}
Synchrotron radiation techniques ( $\mu$-XRF and $\mu$ XANES) were applied to the study of organic-rich phosphatized limestones of NW Greece (Epirus). The results revealed uranium accumulation in areas of the material containing, among others, carbonate apatite (francolite) and organic matter. The $\mathrm{U} L_{3}$-edge of $\mu$-XANES spectra showed that uranium was present in tetravalent form. U-bearing francolite crystals were separated from the rock and characterized by Raman spectroscopy and microprobe. The analysis of the crystals also indicated the presence of sodium and sulfur. The uranium presence in the crystals was also visualized, after neutron irradiation and etching, by the observation of the fission tracks.
\end{abstract}

Keywords Uranium · Francolite Phosphatized limestones $\cdot$ Raman $\cdot \mu$-XRF $\cdot \mu$-XANES $\cdot$ Fission tracks

I. T. Tzifas

tzifioan@chem.auth.gr

1 Department of Chemistry, Aristotle University of Thessaloniki, 54124 Thessaloniki, Greece

2 Research Group Thermochronology and Archaeometry, Institute of Earth Sciences, University of Heidelberg, Postfach 103980, 69029 Heidelberg, Germany

3 Department of Geology and Geoenvironment, University of Athens, Panepistimioupolis, 15784 Zografou, Greece

4 ANKA Synchrotron Radiation Facility, Karlsruhe Institute of Technology, Hermann-von-Helmholtz-Platz 1, 76344 Eggenstein-Leopoldshafen, Germany

5 Center for Electron Nanoscopy, Technical University of Denmark, 2800 Kongens Lyngby, Denmark

6 Departamento de Petrologia e Metalogenia, Instituto de Geociências e Ciências Exatas, Universidade Estadual Paulista - Julio de Mesquita Filho, Av. 24-A, 1515, Rio Claro, SP 13506-900, Brazil

\section{Introduction}

Apatite is a group of phosphate minerals containing high concentration of $\mathrm{OH}^{-}, \mathrm{F}^{-}$and $\mathrm{Cl}^{-}$in their crystals. The naturally occurring apatite has as general chemical formula $\mathrm{Ca}_{10}\left(\mathrm{PO}_{4}\right)_{6}(\mathrm{OH}, \mathrm{F}, \mathrm{Cl})_{2}$. Apatite is the tenth most abundant mineral on Earth and the most abundant naturally occurring phosphate $[1,2]$.

The uniqueness of apatite lies in the ability of its structure to accommodate and adapt to substitution in both cation and anion sites [1, 3, 4]. Rakovan et al. [5] reported the structural characterization of $\mathrm{U}^{6+}$ in apatite as the first step in the investigation of $\mathrm{U}$ and $\mathrm{Th}$ incorporation in its structure $[6,7]$. The study of this group of minerals as potential solid-state radioactive waste repository was also reported in the literature $[8,9]$ and for this reason, many studies based on the sorption/adsorption of $U$ and other radionuclides in the apatite structure have been carried out [10-13]. Apatite, a mineral fundamental in controlling the rare-earth and trace element variation in rocks [14], is valuable in the fission-track determination of rates and dates in geologic processes [15-17].

Francolite [18] is a particular species of the apatite group corresponding to carbonate apatite. The mineral was named after its occurrence at Wheal Franco, Devon, England. The information about the presence and role of carbonate in the structure of this mineral is still rather limited $[19,20]$. Perdikatsis [21] studying pure francolite from the Epirus region (Greece) by X-ray diffraction (XRD), concluded that there is a phosphate substitution by carbonate groups. His results also agree with previous findings [22-24]. Schuffert et al. [25] tried to explain the substitution of phosphates by carbonates in natural francolites modelling the results obtained from the investigation of 37 samples of synthetic francolite with $\mathrm{CO}_{3}{ }^{2-}$-concentration 
between 0.0 and $9.0 \mathrm{wt} \%$. Infrared absorption spectra of a natural carbonate fluorapatite were presented in the literature in 1990 however without further chemical and X-ray diffraction information and data [26]. On the other hand, Ivanova et al. [27] and Fleet and Liu [28-31] presented Rietveld and single-crystal X-ray diffraction data describing a possible substitution mechanism of phosphate by carbonate ions in synthetic fluor- and hydroxy-apatite. Petkova and Yaneva [32] evidenced by infrared spectroscopy (IR), X-ray diffraction (XRD) and thermogravimetry/diffrential thermal analysis (TG/DTA) the isomorphic substitution of phosphate by carbonate groups in Syrian carbonate apatite upon mechanochemical activation and Kostova et al. [33] the positional redistribution of carbonate ions in the structure of sedimentary apatite as effect of high energy milling. The role of the water presence in the structure of francolite is also rather controversial and not completely understood. According to literature, the association of water with apatites may be a key factor in the preference of syn-thetic low temperature apatites for B-type carbonate substitution for phosphate [34, 35]. On the other hand, for particular species of apatite, such as $\mathrm{Ca}_{10}\left(\mathrm{PO}_{4}\right)_{6}(\mathrm{OH})_{2}$ or $\mathrm{Sr}_{10}\left(\mathrm{PO}_{4}\right)_{6} \mathrm{~F}_{2}$, presenting nearly total B-type carbonate substitution, there is no correlation between the number of water molecules in the channels and the weight percentage of carbonate. This lack of correlation would be expected only when there is no competition between water and carbonate in the apatite channels [36].

The presence of carbonate apatites as mineral component of vertebrate bones, teeth and kidney stones is also still quite controversial and not completely clarified.

The objective of this study was to investigate the presence of uranium in organic-rich phosphatized limestones of Epirus region (NW Greece) and especially its association with apatites and francolite crystals as well as with organic matter. It should be noted that there is no generally accepted structural study of the $\mathrm{U}$ location in naturally occurring apatites and in particular in francolites. The results of the study are expected to contribute to a better understanding of the geochemistry and migration/immobilization of uranium into the geological environment of NW Greece and additionally to the elucidation of the redox phenomena taking place.

\section{Experimental part}

\section{Sampling area and treatment of the samples}

The sampling region was mainly selected on the basis of previous unpublished internal reports by the Greek Atomic Energy Commission (GAEC) and Institute of Geology and Mineral Exploration (IGME) concerning radiometric irregularities in the Mesozoic sedimentary rocks of NW Greece and particularly in the mountainous Epirus region [37] The region under investigation, which belongs to the Ionian geotectonic zone of NW Greece (Epirus), is shown in Fig. 1 [38, 39]. The sedimentary formation, where the samples were collected is an organic rich brecciated phosphatized limestone. This particular formation extends in $2 \mathrm{~km}$ approximately along the road of the region of Perivleptos, which is located $10 \mathrm{~km} \mathrm{~N}-\mathrm{NW}$ of the city of Ioannina. The sampling (in total six samples of $1-2 \mathrm{~kg}$ weight each) was performed from the outcrop of the first appearance of the formation to its end. Specifically, the sampling locations were selected by surveying the suspected sedimentary formations by means of a portable radiation counter with $\mathrm{NaI}(\mathrm{Tl})$ detector (Canberra-MCB2). The specimens presenting enhanced radiation consisted of brecciated phosphatized limestones and were partially rich in organic matter.

The samples were crushed using a jaw crusher, pulverized by milling and washed with water. Heavy mineral separation was carried out in four steps in order to obtain concentrates of apatite crystals. In the first step, heavy liquid separation was performed using $80 \%$ sodium polytungstate (LST Fastfloat, density: $2.8 \mathrm{~kg} / \mathrm{m}^{3}$ ). This step was followed by magnetic separation of the $>2.8 \mathrm{~kg} / \mathrm{m}^{3}$ fraction by means of a Frantz magnetic separator. The nonmagnetic fraction was further processed by a solution of

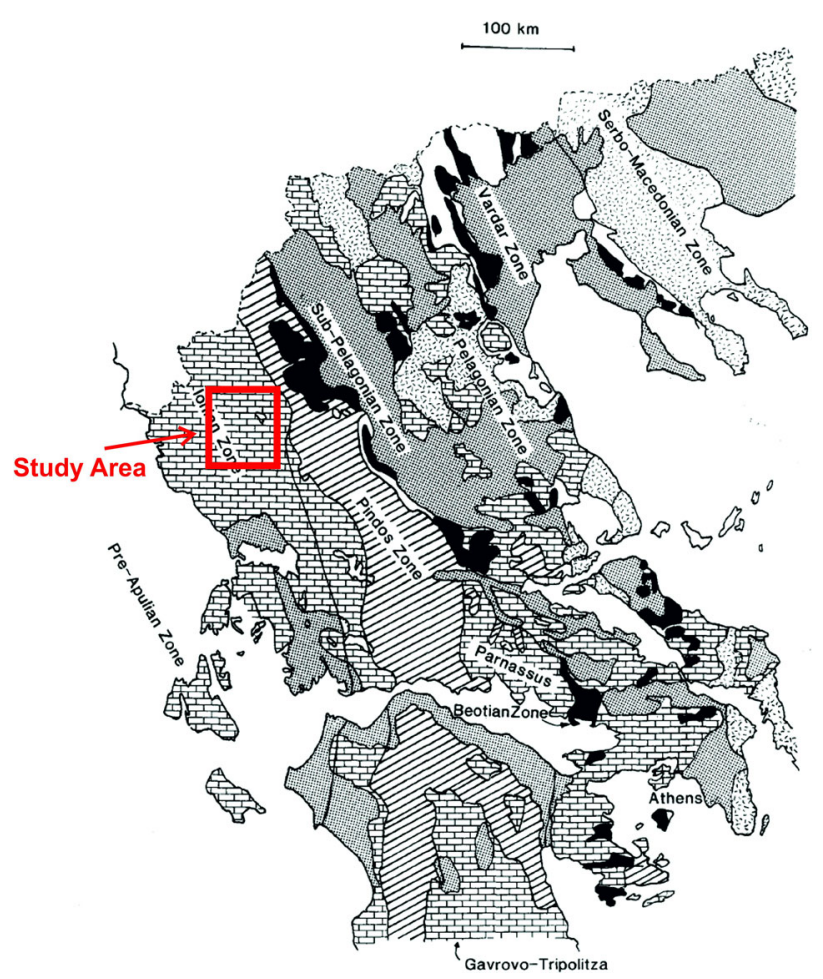

Fig. 1 Location of the studied region (modified after Robertson et al. [40]) 
methylene iodide and acetone (density: $3.2 \mathrm{~kg} / \mathrm{m}^{3}$ ) in order to separate the apatite crystals and finally by pure methylene iodide (density: $3.3 \mathrm{~kg} / \mathrm{m}^{3}$ ) to receive the zircon $\left(\mathrm{ZrSiO}_{4}\right)$ microcrystals.

\section{Sample characterization}

The chemical characterization of the separated crystals was performed on a JEOL JXA-8230 Superprobe Electron Probe Microanalyzer at the Department of Petrology and Metalogenesis of the Institute of Geosciences and Sciences of the Paulista State University (Brasilia). Energy Dispersive Spectra (EDS) were acquired with a silicon drift detector with energy resolution (FWHM) of $129 \mathrm{eV}$ for $\mathrm{Mn}-\mathrm{K} \alpha$, at $3000 \mathrm{cps}$; Wavelength Dispersive Spectroscopy (WDS) qualitative scans were performed with LDE1, TAP, PETL and LIFH crystals and dwell time of $60 \mathrm{~ms}$ in position steps of $50 \mu \mathrm{m}$. The standardization was performed measuring the $\mathrm{FK} \alpha, \mathrm{CaK} \alpha$ and $\mathrm{PK} \alpha$ in F-apatite, $\mathrm{SiK} \alpha$ in wollastonite, $\mathrm{UM} \alpha$ in $\mathrm{UO}_{2}, \mathrm{ClK} \alpha$ in sodalite and $\mathrm{SK} \alpha$ in pyrite and using acceleration voltage of $15 \mathrm{kV}$, current of $20 \mathrm{nA}$, intergration time of $10 \mathrm{~s}$ for peak and $5 \mathrm{~s}$ for background. For WDS quantitative analyses acceleration voltage was applied at $15 \mathrm{nA}$ in order to minimize destruction of the crystals under investigation. The beam diameter was $10 \mu \mathrm{m}$.

Raman spectroscopy measurements were performed at the University of Heidelberg using a Horiba iHR320 Raman Spectrometer, equipped with a $532 \mathrm{~nm}$ Laser (green) and a Horiba Superhead as optional confocal optic.

\section{Fission track measurements}

The apatite and francolite grains were embedded in epoxy resin, cut and polished in order to reveal their internal surface. Uranium free mica foils were attached to the samples, which were irradiated by neutrons, along with CN5 neutron dosimeter glasses, at the FRM II high flux research reactor of the Technical University of Munich at Garching. After the irradiation and decay of the induced radioactivity, the mica foils were etched for $20 \mathrm{~min}$ by $48 \% \mathrm{HF}$ in ambient temperature $\left(20^{\circ} \mathrm{C}\right)$. The fission tracks were then visualized by optical microscopy.

\section{Synchrotron radiation measurements}

Synchrotron radiation (SR) micro-X-ray fluorescence $(\mu-$ $\mathrm{XRF})$ and X-ray absorption near edge structure ( $\mu$ XANES) spectra were obtained using powders and polished sections in the SUL-X beamline of the Laboratory for Environmental Studies of the ANKA facility (Karlsruhe Institute of Technology, Germany) [41]. The sample area of the thin polished section of the phosphatized limestone to be analyzed by $\mu$-XRF was selected using an optical microscope. The intensities of the $\mathrm{Ca}, \mathrm{P}, \mathrm{S}, \mathrm{Y}$ and $\mathrm{U}$ fluorescence emission lines excited by $17.5 \mathrm{keV} \mathrm{X}$-rays were simultaneously determined by a 7-element $\mathrm{Si}(\mathrm{Li})$ solid state detector. On areas with elevated uranium concentration $\mu$-XANES data were recorded at the $\mathrm{U} L_{3}$-edge (about $17.170 \mathrm{keV}$ ). The powder samples measured as pellets were prepared by mixing the sample with a binding agent (cellulose). The uranium minerals uraninite $\left(\mathrm{UO}_{2}\right)$ and shoepite $\left[\mathrm{UO}_{2}(\mathrm{OH})_{2}\right]$ as well as Durango fluorapatite were used as reference materials.

\section{Results and discussion}

The geological formation under investigation seems to be a matrix supported poorly sorted monomictic breccia produced by rock fragmentation due to faulting or other tectonic processes. The matrix of the breccia consists primarily of the cementing material, but it also contains sand and/or silt sized clasts cemented together among the coarser clasts. According to previous work [37], the cement binding the clasts consists of black organophosphate material (organic matter and apatite) and calcite.

The separated inorganic phases were mainly calcite, apatites and francolites (carbonate apatites). The latter had optically different appearance than the classic apatite and, more specifically, appeared as opaque crystals without a specific shape showing different shades of brown. The francolites were identified by Raman spectroscopy combined with SEM/EDS microanalysis. The Raman spectra obtained (Fig. 2) were characterized by bands belonging to both carbonates and phosphates groups [42, 43].

The brown color of the francolite crystals was probably due to a coating created by the interaction of their surface with the organic matter $[44,45]$ or originating from the high participation of carbonate part in its lattice. The

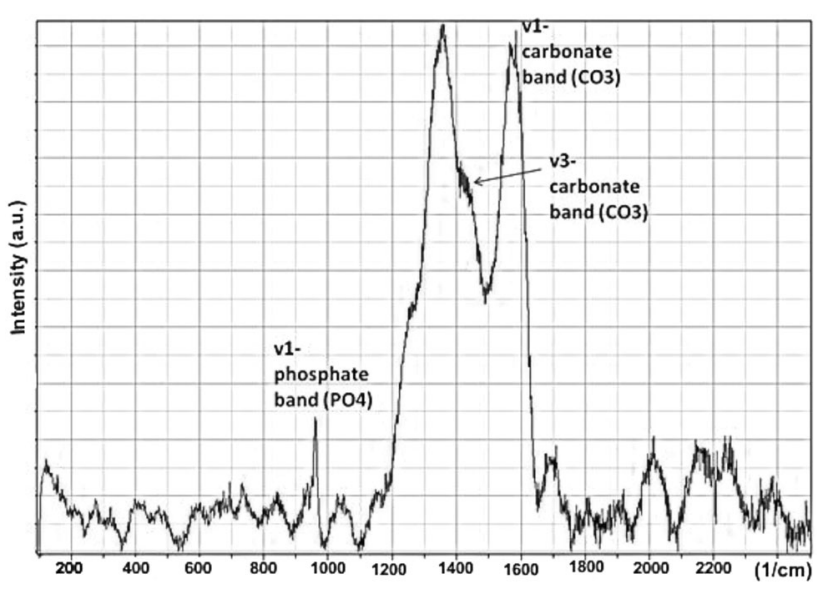

Fig. 2 Raman spectrum of francolite 
microprobe analysis of the crystals showed that the mineral was a uranium-enriched sulfur- and sodium bearing carbonate fluorapatites. The presence of uranium in the francolite crystals was additionally evidenced by the enhanced number of fission tracks revealed in the attached uranium free mica foils after neutron irradiation and etching (Fig. 3). The number of fission tracks originating from the francolite crystals could not be quantified because of their enhanced uranium content. This finding confirming the uranium presence in sedimentary francolite crystals has not been, to our knowledge, previously reported in the literature.

On the other hand, only few studies on the chemical composition of francolites have appeared so far in the literature [22, 46, 47]. The elemental mapping of the studied francolite performed by microprobe showed that $\mathrm{Ca}, \mathrm{P}, \mathrm{S}$, and $\mathrm{Na}$ were not homogenously distributed in the crystals (Fig. 4).

SR-based measurements of the U-bearing organic rich phosphatized limestone were performed in order to obtain information about the uranium oxidation state in the samples. SR $\mu$-XRF maps were used to examine the distribution of uranium in the samples in order to select the target areas for $\mu$-XANES measurements. The SR $\mu$-XRF study (Fig. 5) revealed that $U$ was accumulated, along with $P, Y$ and most likely $S$, in certain areas of the dark organic-rich part of the rock containing, according to previous XRDand SEM/EDS measurements, enhanced concentrations of apatites and amorphous organic matter. The areas with very low $\mathrm{U}$ and high $\mathrm{Ca}$ concentrations mainly consisted of calcite and, in a lesser extent, of dolomite.

The position of the $\mathrm{U} L_{3}$-edge $\left(2 \mathrm{p}_{3 / 2}\right.$ orbital) in preliminary $\mu$-XANES spectra indicated the presence of $\mathrm{U}^{4+}$ associated to apatite-group minerals and/or organic matter. Figure 6 presents the position of the uranium edge of the investigated phosphatized limestone in comparison with those obtained for uraninite $\left(\mathrm{UO}_{2}\right)$ and shoepite $\left[\mathrm{UO}_{2}(\mathrm{OH})_{2}\right]$ used as reference materials. Under oxidizing conditions, typical of surface waters and groundwater systems, the aqueous speciation of $\mathrm{U}^{6+}$ determine the partitioning of uranium onto mineral surfaces or in their structure by the reduction of $\mathrm{U}^{6+}-\mathrm{U}^{4+}$. Oxidized $\mathrm{U}^{6+}$ is highly soluble as the uranyl ion $\mathrm{UO}_{2}{ }^{2+}$, whereas the solubility of $\mathrm{U}^{4+}$ is controlled by insoluble oxides such as uraninite. Oxidation state analyses contribute to a better understanding of the geochemistry and migration/immobilization of uranium into the geological environment and additionally to the elucidation of the redox phenomena taking place.

The ability of apatite to accommodate several foreign elements, including actinides, in its lattice is well-known and of great environmental importance. Monovalent $\left(\mathrm{Na}^{+}\right.$, $\left.\mathrm{K}^{+}\right)$, divalent $\left(\mathrm{Sr}^{2+}, \mathrm{Pb}^{2+}, \mathrm{Ba}^{2+}, \mathrm{Mn}^{2+}, \mathrm{Cd}^{2+}\right)$, trivalent $\left(\mathrm{REE}^{3+}\right)$, as well as tetravalent $\left(\mathrm{Th}^{4+}, \mathrm{U}^{4+}\right)$ and hexavalent $\left(\mathrm{U}^{6+}\right)$ cations have been reported to substitute calcium in the apatite structure [3, 5-7, 48]. Rakovan et al. [5], observed, analyzing extended X-ray absorption fine structure (EXAFS) data, the Ca-substitution (Ca1 site) by $\mathrm{U}^{6+}$
Fig. 3 Apatite (a) and francolite (c) crystals and the corresponding induced fission tracks (b) and (d) in the attached uranium free mica foils after neutron irradiation
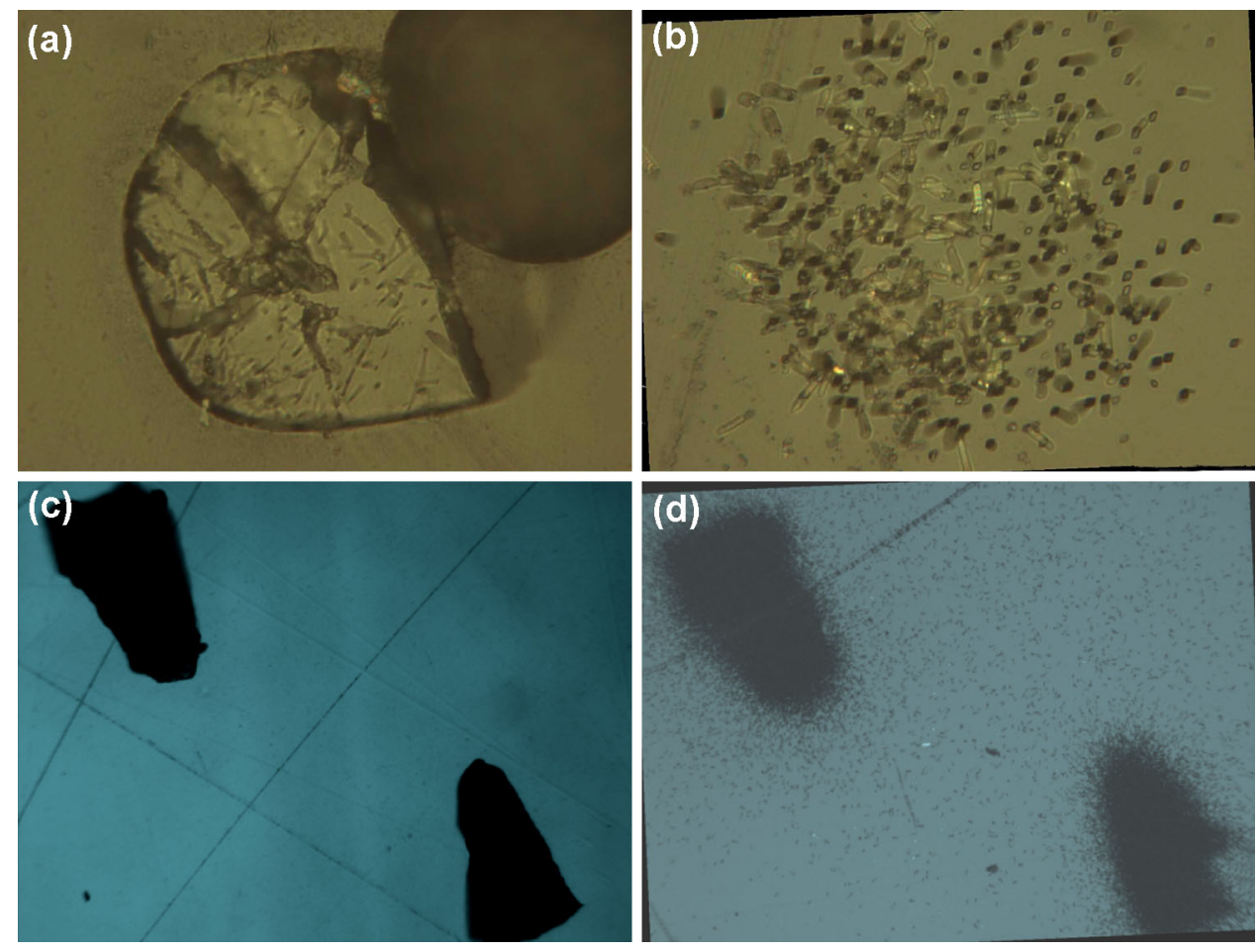
Fig. 4 Microprobe elemental maps of a francolite crystal
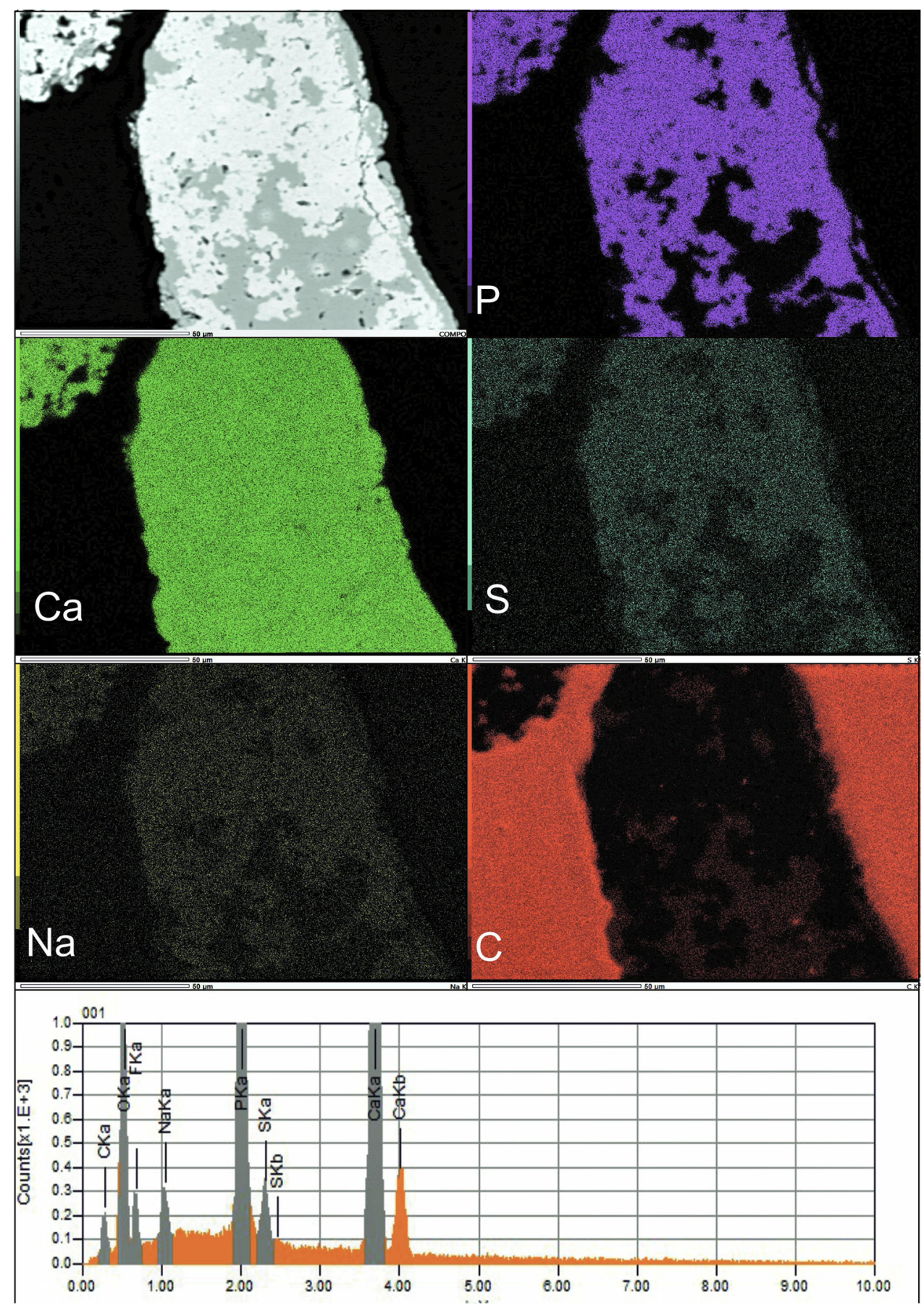

in synthetic apatite grown at $1350{ }^{\circ} \mathrm{C}$. In addition, Luo et al. [6] reported, also based on XRD and XANES data, that $\mathrm{U}^{4+}$ can also be incorporated in Ca-sites of U-doped synthetic fluorapatite. Structure refinements indicated that, in this case, $\mathrm{U}$ substitutes $\mathrm{Ca}$ almost exclusively into the $\mathrm{Ca}_{2}$ sites with site occupancy ratios $\mathrm{UCa}_{2} / \mathrm{UCa}_{1}$ ranging from 5.00 to 9.33 . The occurrence of $\mathrm{U}^{4+}$ in calcite, formed at low temperatures, is considered to be less possible.

Combining the SR $\mu$-XRF maps of the bulk rock with those of the francolites carried out by SEM/EDS — could be concluded that the uranium was concentrated in the organic rich part of the phosphatized limestones and more specifically in the francolite structure. The positive correlation between uranium and phosphor additionally strengthen this conclusion [49, 50]. Previous attempts to explain the presence of uranium in sedimentary apatite (e.g. [51]) were based on the similarity of the ionic radii of the elements and on the assumption that uranium may partly substitute calcium in the carbonate apatite lattice. At this point, it should also be emphasized that all the studies about 
Fig. 5 Optical image of the polished section of the U-bearing limestone (upper left) and qualitative $\mathrm{SR} \mu$-XRF elemental maps. The dark side corresponds to the organic-rich component, where ( $\mathrm{U}$ and $\mathrm{P}$ ) is mostly accumulated, while the bright one to Ca-carbonate
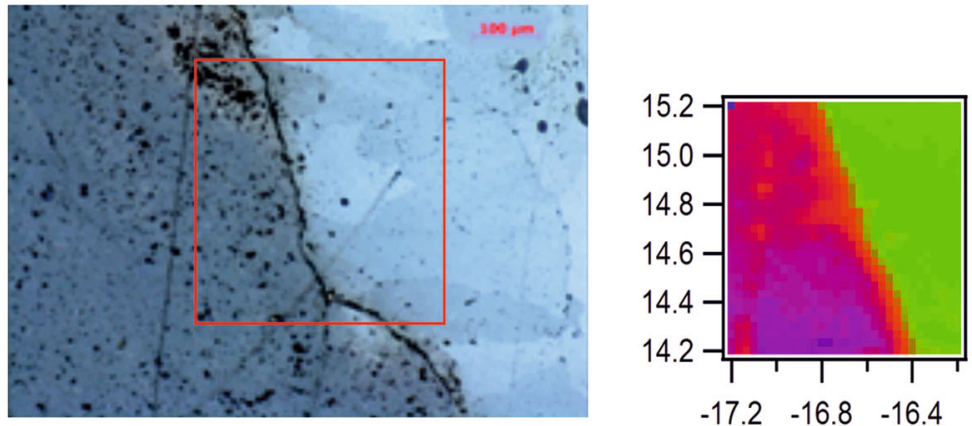

roi_3 [mm]
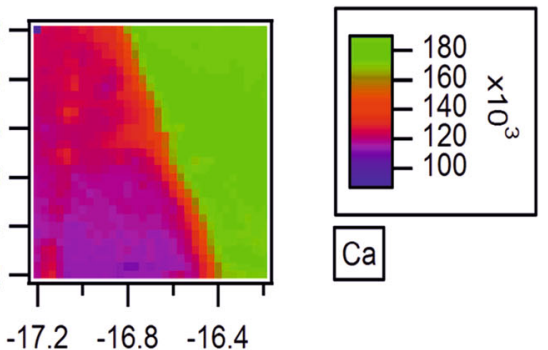

$\mathrm{Ca}$
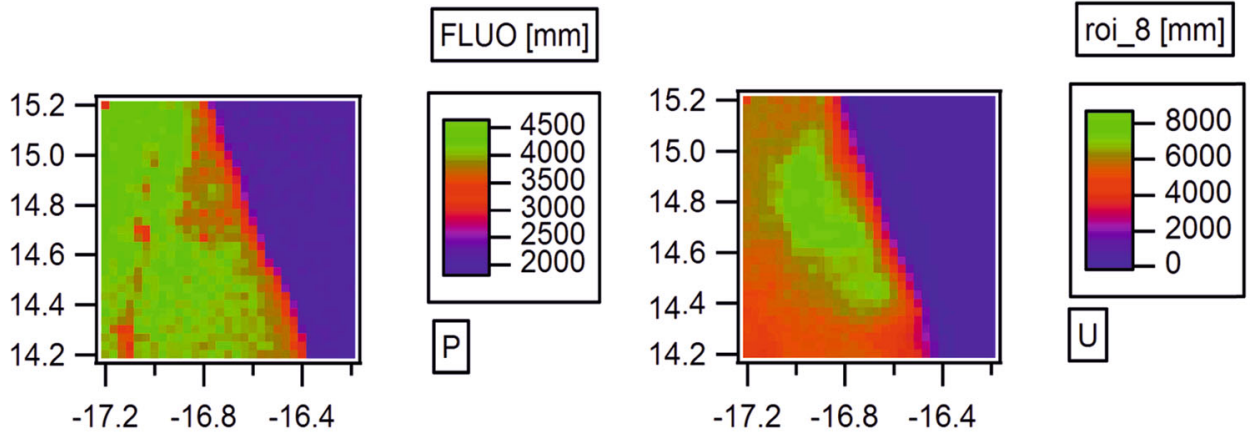

U

roi_2 [mm]
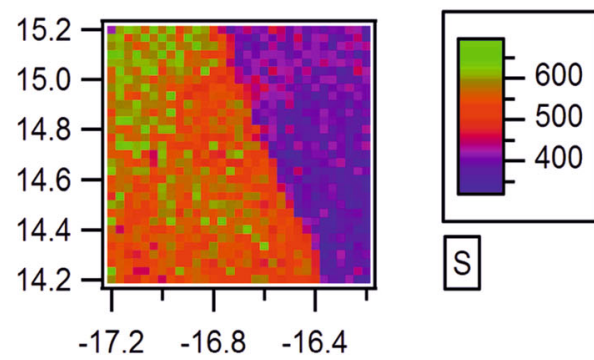

S

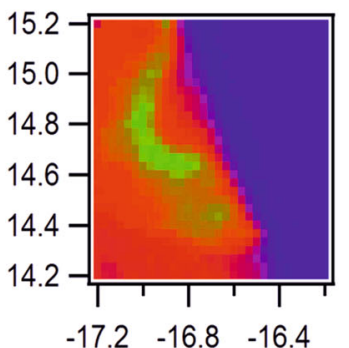

roi_10 [mm]

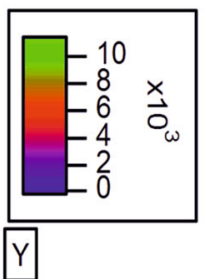

uranium in apatite structure concerned fluorapatites and chloroapatites [5, 6] and there were no specific studies about uranium in carbonate apatite/francolite $\left(\left[\mathrm{Ca}_{5}\left(\mathrm{PO}_{4}, \mathrm{CO}_{3}\right)_{3}(\mathrm{~F}, \mathrm{OH})\right]\right)$ occurring, along with fluor- and hydroxy-apatite.

\section{Conclusions}

The organic rich limestones of NW Greece (Epirus region) exhibit radioactivity due to the enhanced uranium content. Organic matter, apatites, francolites (carbonate apatites) and calcite are the main phases of the rock. Francolites were identified by combining microprobe data with Raman spectroscopy. $\mu$-XRF elemental mappings applied to polished thin section of the sample showed that the uranium exclusively existed in the organic rich part 
(apatites + francolites + organic matter). Moreover, uranium was positively correlated with the $\mathrm{P}$, while $\mathrm{S}$ was also present. The density of homogenously distributed fission tracks highlighted the high $\mathrm{U}$ content. $\mu$-XANES study revealed that the uranium existed in the $\mathrm{U}^{4+}$ oxidation state. Furthermore, the fission track results showed that francolites could be a perfect candidate for thermochronology dating due to their high $\mathrm{U}$ content.

Acknowledgments The study was partly supported by a DAAD(UNIBRAL: 56265621) and a BMBF-Grant (05K13VH1) provided to the author U.A. Glasmacher. Synchrotron radiation beams were provided by the ANKA facility within the frame of the ANS-114 research project. The assistance of Drs. R. Steininger and T. J. Mertzimekis as well as of the ANKA technical staff during the experiments is thankfully acknowledged. We also thank Prof. P. C. Hackspacher for the support provided to us. Finally, many thanks to the Laboratory Manager of the Research Group Thermochronology and Archaeometry, Mrs. Margit Brückner for her assistance for the fission track measurements.

\section{References}

1. Hughes JM, Rakovan J (2002) The crystal structure of apatite, $\mathrm{Ca}_{5}\left(\mathrm{PO}_{4}\right)_{3}(\mathrm{~F}, \mathrm{OH}, \mathrm{Cl})$. In: Kohn M, Rakovan JF, Hughes JM (eds) Phosphates: geochemical, geobiological and materials importance. Reviews in mineralogy and geochemistry, vol 48. Mineralogical Society of America, Washington DC, pp 1-12

2. Hughes JM, Rakovan J (2015) Structurally robust, chemically diverse: apatite and apatite supergroup minerals. Elements 11(3): 165-170

3. Pan Y, Fleet ME (2002) Composition of apatite-group minerals: substitution mechanisms and controlling factors. In: Kohn M, Rakovan JF, Hughes JM (eds) Phosphates: geochemical, geobiological and materials importance. Reviews in mineralogy and geochemistry. Mineralogical Society of America, Washington DC, pp 13-49

4. Pasero M, Kampf AR, Ferraris C, Pekov IV, Rakovan J, White T (2010) Nomenclature of apatite supergroup minerals. Eur J Miner 22:163-179

5. Rakovan J, Reeder RJ, Elzinga EJ, Cherniak D, Tait CD, Morris DE (2002) Characterization of U(VI) in the apatite structure by X-ray absorption spectroscopy. Environ Sci Technol 36(14):3114-3117

6. Luo Y, Rakovan J, Elzinga E, Pan Y, Lupulescu MV, Hughes J (2011) Crystal chemistry of $\mathrm{Th}$ in fluorapatite. Am Mineral 96:23-33

7. Luo Y, Rakovan J, Hughes J, Pan Y (2009) Site preference of U and $\mathrm{Th}$ in $\mathrm{Cl}, \mathrm{F}$. Sr apatites Am Miner 94:345-351

8. Ewing RC, Wang LM (2002) Phosphates as nuclear waste forms. In: Kohn M, Rakovan JF, Hughes JM (eds) Phosphates: geochemical, geobiological and materials importance. Reviews in mineralogy and geochemistry, vol 48. Mineralogical Society of America, Washington D.C, pp 673-699

9. Borkiewicz O, Rakovan J, Cahill C (2010) Time resolved in situ studies of apatite formation pathways in aqueous solutions. Am Miner 95:1224-1236

10. Kanai Y (2003) Characterization of $U$ series nuclides in geological materials by selective leaching method. J Radioanal Nucl Chem 255(2):319-323
11. Moore CR, Gasser M, Awwad N, Holt CK, Salas MF, Hasan A, Hasan AM, Zhao H, Sanchez AC (2005) Sorption of plutonium(VI) by hydroxyapatite. J Radioanal Nucl Chem 263(1):1588-2780

12. Galamboš M, Suchánek P, Rosskopfová O (2012) Sorption of anthropogenic radionuclides on natural and synthetic inorganic sorbents. J Radioanal Nucl Chem 293(2):613-633

13. Popa K (2013) Sorption of uranium on lead hydroxyapatite. J Radioanal Nucl Chem 298(3):1527-1532

14. Hughes JM, Cameron M, Mariano AN (1991) Rare earth element ordering and structural variations in natural rare- earth bearing apatites. Am Miner 76:1165-1173

15. Glasmacher U, Zentilli M, Grist AM (1997) Apatite Fission Track thermochronology of Paleozoic sandstones and the Hillintrusion at the northern part of the Linksrheinisches Schiefergebirge, Germany. In: Van den Haute P, De Corte F (eds) Advances in Fission-Track Geochronology. Kluwer Academic Publishers, Schiefergebirge, pp 151-172

16. Glasmacher UA, Mann U, Wagner GA (2002) Thermotectonic evolution of the Barrandian, Czech Republic, as revealed by apatite fission-track analysis. Tectonophysics 359:381-402

17. Lisker F, Ventura B, Glasmacher UA (2009) Apatite thermochronology in modern geology. Spec Pub Geol Soc London 324:1-23

18. Sandell EB, Hey MH, McConnell D (1939) The composition of francolite. Mineral Mag 25:395-401

19. McConnell D (1970) Apatite: its crystal chemistry, mineralogy, utilization and geologic and biologic occurrences. In: Bentor YE (ed) Applied mineralogy, vol 5. Springer, New York, p 111

20. McArthur JM (1985) Francolite geochemistry compositional controls during formation, diagenesis, metamorphism and weathering. Geochim Cosmochim Acta 49:23-35

21. Perdikatsis B (1991) X-ray powder diffraction study of francolite by the Rietveld method. Mater Sci Forum 79-82:809-814

22. McClellan GH (1980) Mineralogy of carbonate-fluorapatite. J Geol Soc Lond 137:675-681

23. McClellan GH, Van Kauwenbergh SJ (1990) Mineralogy of sedimentary apatites. In: Notholt AJG, Jarvis I (eds) Phosphorite research and development, vol 52. Geological Society Special Publication, London, pp 23-31

24. Binder G, Troll G (1989) Coupled anion substitution in natural carbon-bearing apatites. Contrib Miner Petrol 101(4):394-401

25. Schuffert JD, Kastner M, Emanuelle G, Jahnke RA (1990) Carbonate-ion substitution in francolite: a new equation. Geochim Cosmochim Acta 54:2323-2328

26. Baumer A, Ganteaume M, Klee W (1985) Determination of OH ions in hydroxyfluorapatite by infrared spectroscopy. Bull Miner 108:145-152

27. Ivanova TI, Frank-Kamenetskaya OV, Kol'tsov AB, Ugolkov VL (2001) Crystal structure of calcium-deficient carbonated hydroxyapatite. thermal decomposition. J Solid State Chem 160:340-349

28. Fleet ME, Liu X (2004) Location of type B carbonate ion in type A-B carbonate apatite synthesized at high pressure. J Solid State Chem 177:3174-3182

29. Fleet ME, Liu X (2003) Carbonate apatite type A synthesized at high pressure: new space group P3 and orientation of channel carbonate ion. J Solid State Chem 174:412-417

30. Fleet ME, Liu X (2005) Local structure of channel ions in carbonate apatite. Biomaterials 26:7548-7554

31. Fleet ME, Liu X (2008) Accommodation of the carbonate ion in fluoapatite synthesized at high pressure. Am Miner 93:1460-1469

32. Petkova V, Yaneva V (2010) Thermal behavior and phase transformations of nanosized carbonate apatite (Syria). J Therm Anal Calorim 99:179-189 
33. Kostova V, Petrova NL, Petkova V (2013) The high energy milling effect on positional redistribution of $\mathrm{CO}_{3}$-ions in the structure of sedimentary apatite. Bul Chem Commun 45(4):601-606

34. Pasteris JD, Yoder CH, Wopenka B (2014) Molecular water in nominally unhydrated carbonated hydroxylapatite: the key to a better understanding of bone mineral. Am Miner 99:16-27

35. Peroos S, Du Z, De Leeuw NH (2006) A computer modeling study of the uptake, structure and distribution of carbonate defects in hydroxyl-apatite. Biomaterials 27:2150-2161

36. Goldenberg E, Wilt Z, Schermerhorn D, Pasteris JD, Yoder CH (2015) Structural effects on incorporated water in carbonated apatites. Am Miner 100:274-280

37. Tzifas ITr, Godelitsas A, Magganas A, Androulakaki E, Eleftheriou G, Mertzimekis T, Perraki M (2014) Uranium-bearing phosphatized limestones of NW Greece. J Geochem Explor 143:62-73

38. Tsikos H, Karakitsios V, Van Breugel Y, Walsworth-Bell B, Bombardiere L, Petrizzo MR, Sinninghe Damst JS, Schouten S, Erba E, Silva IP, Farrimond P, Tyson RV, Jenkyns HC (2004) Organic-carbon deposition in the cretaceous of the ionian basin, NW Greece: the paquier event (OAE 1b) revisited. Geol Mag 141:401-416

39. Kafousia N, Karakitsios V, Mattioli E, Kenjo S, Jenkyns HC (2014) The toarcian oceanic anoxic event in the ionian zone, Greece. Palaeogeogr Palaeocl 393:135-145

40. Robertson AHF, Clift PD, Degnan PJ, Jones G (1991) Palaeogeographic and palaeotectonic evolution of the eastern mediterranean neotethys. Palaeogeogr Palaeocl 87:289-343

41. Key parameters of the SUL-X beamline. ANKA facility, Karlsruhe Institute of Technology, Karlsruhe. https://www.anka.kit. edu/1629.php
42. Antonakos A, Liarokapis E, Leventouri T (2007) Micro-Raman and FT-IR studies of synthetic and natural apatites. Biomaterials 28:3043-3054

43. Penel G, Leroy G, Bres E (1998) Micro Raman spectral study of the $\mathrm{PO}_{4}$ and $\mathrm{CO}_{3}$ vibrational modes in synthetic and biological apatites. Calcifi Tissue Int 63(6):475-481

44. Suess E (1970) Interaction of organic compounds with calcium carbonate-I. Association phenom geochemical implications. Geochim Cosmochim Acta 34:157-168

45. Suess E (1973) Interaction of organic compounds with calcium carbonate-II. Organo carbonate association in recent sediments. Geochim Cosmochim Acta 37:2435-2447

46. Barbarand J, Hurford T, Carter A (2002) Variation in apatite fission-track length measurement: implications for thermal history modeling. Chem Geol 198:77-106

47. Barbarand J, Wood Carter A, Hurford TI (2003) Compositional and structural control of fission-track annealing in apatite. Chem Geol 198:107-137

48. Rakovan J, Hughes JM (2000) Strontium in the apatite structure: strontian fluorapatite and belovite-(Ce). Can Miner 38:839-845

49. Soudry D, Ehrlich S, Yoffe O, Nathan Y (2002) Uranium oxidation state and related variations in geochemistry of phosphorites from the Negev (southern Israel). Chem Geol 189(3-4):213-230

50. Altschuler ZS, Clarke RS, Young EJ (1958) Geochemistry of uranium in apatite and phosphorite. US Geol Surv Prof Pap 314(D):45-90

51. Baturin GN, Kochenov AV (2001) Uranium in phosphorites. Lithol Miner Resour 36(4):303-321 